\title{
KKNI-BASED CURRICULUM PROGRAM EVALUATION IN FEBI, STATE ISLAMIC UNIVERSITY OF NORTH SUMATRA MEDAN
}

\author{
Syafaruddin $^{1}$, Amiruddin Siahaan ${ }^{2}$, Suasana Nikmat Ginting ${ }^{3}$ \\ 1,2,3 State Islamic University of North Sumatra Medan, Indonesia \\ *Correspondence: suasananikmatginting@uinsu.ac.id
}

\begin{abstract}
This paper aims to analyze the evaluation of the KKNI-based curriculum program at the Faculty of Islamic Economics and Business (FEBI) UIN North Sumatra Medan. The curriculum evaluation model used is the CIPP model (Context, Input, Process, Product). This study used a qualitative approach, then data was obtained through observation, interviews, questionnaires, and documentation techniques as well as various sources. The results of this study indicate that (1) Context, from this aspect, FEBI UIN North Sumatra Medan applies an KKNI-based curriculum referring to Presidential Regulation No. 8 of 2012; (2) Inputs, including lecturer's RPS, quizzes, assignments, learning participation, mid-semester exams and end-semester exams; (3) Process, including monitoring of internal quality assurance units at the FEBI and university levels at UIN North Sumatra Medan, as well as external quality assurance in the context of institutional and study program accreditation; (4) Product, through formative evaluation (such as group assignments, quizzes, individual assignments, exams) and empirical evaluation (behavior and student participation in the learning process).
\end{abstract}

Keywords: Evaluation of Curriculum Program, KKNI, CIPP Model.

\begin{abstract}
ABSTRAK
Tulisan ini bertujuan untuk menganalisa evaluasi program kurikulum berbasis KKNI di Fakultas Ekonomi dan Bisnis Islam (FEBI) UIN Sumatera Utara Medan. Adapun model evaluasi kurikulum yang digunakan yaitu model CIPP (Context, Input, Process, Product). Penelitian ini menggunakan pendekatan kualitatif, selanjutnya pemerolehan data melalui teknik observasi, wawancara, kuesioner, dan dokumentasi serta beragam sumber. Hasil penelitian ini menunjukkan bahwa (1) Context, dari aspek ini, FEBI UIN Sumatera Utara Medan menerapkan kurikulum berbasis KKNI mengacu pada Peraturan Presiden Nomor 8 Tahun 2012; (2) Input, meliputi RPS dosen, kuis, tugas, partisipasi pembelajaran, ujian tengah semester dan ujian akhir semester; (3) Process, meliputi monitoring dari unit penjamin mutu internal tingkat fakultas FEBI dan universitas di UIN Sumatera Utara Medan, serta penjamin mutu eksternal dalam konteks akreditasi institusi dan program studi; (4) Product, melalui evaluasi formatif (seperti tugas kelompok, kuis, tugas individu, ujian) dan evaluasi empiris (tingkah laku dan partisipasi mahasiswa dalam proses pembelajaran).
\end{abstract}

Kata Kunci: Evaluasi Program Kurikulum, KKNI, Model CIPP.

\section{A. PRELIMINARY}

The curriculum is a complete concept of an educational program that is applied by educational institutions (Westbury, 2016: 783-785). Various styles and curriculum models from time to time have changed and adapted according to the needs of the times (Giamellaro, 2017: 351). Now, the curriculum applied to higher education institutions is a curriculum based on the Indonesian National Qualifications Framework (KKNI). The main orientation of implementing this curriculum is the gradual adjustment of competencies from all agencies in 
Indonesia to the world (field) of work. Thus, graduates from various agencies can compete nationally and globally according to the IQF standards.

Evaluation of the KKNI-based Curriculum Program is a very strategic activity to see and improve the quality of graduates at the Faculty of Islamic Business Economics (FEBI) State Islamic University (UIN) North Sumatra Medan. This is intended to promote and produce graduates who are qualified and have potential, must be able to apply the curriculum system implemented by the government in the world of education currently referring to Presidential Regulation No. 8 of 2012 concerning national qualifications.

Through the national IQF reference, the community and the government can identify a framework for qualification of work skills on the basis of education, training and experience of each individual to gain confidence in being able to work in certain fields according to their skills and soft skills (Wijaya, 2019: 364). On this basis, KKNI becomes a reference for higher education curriculum in Indonesia (Syafaruddin \& MS, 2017: 12). This is because higher education institutions will think more about the opportunities for graduates to be able to compete in the world of work after completing their education.

The curriculum in educational institutions is open to criticism and must be easily transformed in practice (Casmini, 2014: 126). In line with this, Miel in Nasution (2008: 5) states that the curriculum is not passive, but actively contains real and material elements of the state of the educational institution unit. Furthermore, the IQF analysis can be studied through 3 (three) curriculum theories, namely Connected Curricullum Theory, Ladder Curricullum Theory, and Spiral Curricullum Theory (Siregar, 2019: 67-73). The end result of this process is mastery of the interrelationships and structure of a large body of knowledge (M., 2000: 551-557).

The existence of this KKNI will change the way of looking at a person's competence, no longer just a diploma but by looking at the qualification framework agreed upon nationally as the basis for recognizing one's educational outcomes in a broadly accountable and transparent manner (Wijaya, 2019: 364). This is in accordance with the main objective of the $\mathrm{IQF}$, which is to become a tiered qualification framework that can juxtapose, equalize, and integrate the fields of education and the field of job training and work experience in order to provide recognition of work competencies in accordance with the structure of work in various sectors of life (Hutabarat, 2017: 18).

The implementation of the curriculum that refers to the KKNI actually makes it clear what the profile of the graduates of the Faculty of Islamic Business Economics (FEBI) of the 
State Islamic University (UIN) of North Sumatra Medan from each study program looks like and what the learning outcomes obtained by students are. After attending lectures, so that the preparation of the curriculum is truly in accordance with the needs and competencies desired by each study program (Hutabarat, 2017: 18).

The implementation of the IQF Curriculum is a form of quality and characteristic of the Indonesian state associated with the national pattern of education and training implemented in Indonesia. Therefore, it can be understood that KKNI is a form of learning by requiring the PT system to clarify the form of its alumni, thus it can be adjusted to appropriateness from the point of view of analyzing community needs. The KKNI is organized based on the specific needs and objectives of the Indonesian people in order to align the education system and training levels to improve performance in the field of work. The above is a design in order to adapt the system in other countries (Dikti, 2010: 4).

If we look at these developments, higher education/universities in Indonesia face the challenge of how to make serious efforts to increase the human resources of educators. Because, the demands and regulations that are required by the government to be able to teach Strata I (S1) must have a master's education level and so on, if teaching masters, the lecturer must have passed doctoral education

Syafaruddin (2012: 7-8) asserted, there are 5 (five) aspects that become serious challenges for Indonesian education, namely: quality improvement, equity, management efficiency, community participation or participation, and accountability. Furthermore, Daulay (2019: 9) assessing that Islamic education currently faces various problems and challenges that are closely related to quality, culture, and educational competition in the millennial era.

Commitment to prepare practical experts who are "ready to use" in the world of the Islamic finance industry by presenting experts. Thus, the development and development of the field of sharia-based economic science is a form of the seriousness and commitment of the educational institution FEBI UIN North Sumatra Medan.

This seriousness, as can be seen from the guidelines for the quality standards of lecturers and education at UIN North Sumatra Medan to achieve its vision and mission. To realize the National Education System and National Education Standards (SNP), FEBI UIN North Sumatra Medan of course follows the guidelines made by the University in achieving its vision and mission.

Of course, the research that the researcher will do is not a stand-alone study. Based on the literature study that the researcher did, there were several previous studies, including 
First, research conducted by Hutabarat (2017: 20), Jakarta State University postgraduate dissertation entitled Evaluation of the Indonesian National Qualification Policy Framework in Higher Education. The results of the study conclude that the KKNI policy regulated in the Presidential Regulation of the Republic of Indonesia Number 8 of 2012 refers to the Government of the Republic of Indonesia Number 31 of 2006 concerning the National Job Training System, in both laws, the KKNI is set as a reference in determining the qualifications of Indonesian workers, and higher education outcomes.

The same reference is expected to integrate job training graduates and higher education outcomes. The difference between the two laws is Perpres No. 8/2012 regulates the IQF on all types of education, whether formal, non-formal, or informal. Meanwhile, in the Government Regulation on national job training, KKNI is only a reference for job training graduates.

Second, Research conducted Thabrani (2019: 3), Dissertation on the Postgraduate Program of UIN Sumut Medan, with the title Evaluation of Learning Management at MAN Rantau Prapat.The results of this study indicate that the type of curriculum used in Madrasah Aliyah Negeri Rantauprapat consists of three types of curriculum, namely: (1) the 2006 KTSP curriculum, (2) the 2013 science-based curriculum, and (3) the curriculum is prepared by the Madrasah. Aliyah Negeri Rantauprapat.

Third, Creation Wijaya (2019: 364), in the book 70 Years of Prof. Haidar Putra Daulay, MA, Dynamics and Thought of Islamic Education, Classical and Contemporary Studies, with the title Implementation Principles of Curriculum Development of the Indonesian National Qualifications Framework (KKNI). The results of this study indicate that the basic principle developed in the IQF is to assess a person's performance in aspects of science, expertise and skills in accordance with learning outcomes (Learning Out Comes) obtained through the education, training or experience that has been passed. which is equivalent to the qualification description for a given level.

In relation to the educational process, learning outcomes are the final result or accumulation of the process of increasing one's knowledge, expertise and skills obtained through formal, informal or non-formal education. If it is understood larger than the intention, learning outcomes can be understood as the final result of a journey of increasing one's abilities or career paths when he is working. This basic principle is in line with the approach taken by other countries in developing their respective qualification frameworks. 
Fourth, scientific articles Casmini (2014: 131-132), with the title Evaluation and Review of the KKNI-Based BKI Curriculum. If you look at his work, then his research can be analyzed by understanding the activities that are fundamental to curriculum empowerment efforts as part of one of the elements in achieving alumni competence in BKI study programs or majors which are part of the development of the BKI curriculum itself.

Fifth,scientific articles Siagian \& Novatrasio (2012: 340), with the title Analysis of KKNI-Based Curriculum Implementation at Medan State University. The results of this journal explain that there are obstacles to implementing the IQF-based curriculum, namely: First, lecturers are not fully ready to apply the IQF in learning. Second, facilities and infrastructure are also inadequate in developing learning with the IQF concept. A capable information technology system is needed to help students learn digitally. Third, the difficulty of the campus, especially the study program in determining internship partners. The implementation of KKNI at education-based universities such as Medan State University, PPL (Field Experience Program) has been changed to internship. In the previous curriculum, PPL has a weight of 8 credits. The program is held during the seventh semester and campus lectures are abolished. However, in the IQF, the term is changed to internship and only weighs 4 credits. The program is divided into three semesters by determining different partners. This makes it difficult for the campus to find partners as a forum for students to hold internships. The fourth obstacle relates to the subject of the KKNI itself, namely students. Students as the center of attention in implementing this competency-based curriculum have several difficulties which also affect the expected results. In addition to students being constrained by the problem of working time on assignments, students also tend to be less creative, less innovative, and less solutive in participating in KKNI learning. Furthermore, students are less able to use English. This makes it difficult for the campus to find partners as a forum for students to hold internships. The fourth obstacle relates to the subject of the KKNI itself, namely students. Students as the center of attention in implementing this competency-based curriculum have several difficulties which also affect the expected results. In addition to students being constrained by the problem of working time on assignments, students also tend to be less creative, less innovative, and less solutive in participating in KKNI learning. Furthermore, students are less able to use English. This makes it difficult for the campus to find partners as a forum for students to hold internships. The fourth obstacle relates to the subject of the KKNI itself, namely students. Students as the center of attention in implementing this competency-based curriculum have several difficulties which also affect 
the expected results. In addition to students being constrained by the problem of working time on assignments, students also tend to be less creative, less innovative, and less solutive in participating in KKNI learning. Furthermore, students are less able to use English. Students as the center of attention in implementing this competency-based curriculum have several difficulties which also affect the expected results. In addition to students being constrained by the problem of working time on assignments, students also tend to be less creative, less innovative, and less solutive in participating in KKNI learning. Furthermore, students are less able to use English. Students as the center of attention in implementing this competency-based curriculum have several difficulties which also affect the expected results. In addition to students being constrained by the problem of working time on assignments, students also tend to be less creative, less innovative, and less solutive in participating in KKNI learning. Furthermore, students are less able to use English.

Temporary findings from researchers, lecturers in FEBI UIN North Sumatra Medan already understand what KKNI really is, thus their understanding of what KKNI is must also be seen to what extent is followed by the application of each lecturer at FEBI in carrying out teaching and learning process.

FEBI UIN Sumut Medan can be said to have an extraordinary phenomenon among several faculties on the UIN Sumut Medan campus, where if we look at the age of its establishment, the number of interested students enrolling in this faculty is very enthusiastic and meets the desired standards. The phenomenon of FEBI UIN Sumut Medan can be seen from the study programs and the accreditation of each study program in the faculty.

FEBI UIN North Sumatra also has advantages when compared to economics faculties in other general fields, because, in FEBI UIN North Sumatra, in addition to educational material on economics, they also get material that studies subjects with religious nuances. This is because the education system is integrated between the general sciences and the religious sciences.

FEBI UIN Sumut has several study programs, namely: Islamic Economics, with an accreditation score (A), D3 Banking and Finance Management with an accreditation score (B), S1 Sharia Accounting with accreditation (B), S1 Sharia Banking with a grade (B), S1 Sharia Insurance with an accreditation score (B), S1 Management is still a Study Program Permit, S2 Islamic Economics with a B accreditation score, S3 Islamic Economics with an accreditation score of B. Based on these data, from all the existing study programs it can be 
seen that the Islamic Economics department is the major that the highest accreditation value from other study programs.

Furthermore, in-depth research is needed to discuss the evaluation of the KKNI-based curriculum implemented by FEBI UIN North Sumatra Medan. Comprehensively, the researcher uses the CIPP model in order to evaluate the context, input, process, and product from the implementation of the curriculum, which is summarized in the research title, "Evaluation of the KKNI-Based Curriculum Program at FEBI UIN North Sumatra Medan". The results of the KKNI-Based Curriculum evaluation research at FEBI UIN North Sumatra Medan are expected to be theoretically useful to enrich the treasures of knowledge, specifically in curriculum management as part of education management. Then it is useful to be a comparison for researchers who will carry out further research in the context of developing Islamic education management science.

\section{B. METHOD}

This research is focused on analyzing the evaluation of the IQF-based curriculum program. This study intends to examine the implementation of the KKNI-based curriculum program at FEBI UIN North Sumatra Medan, including the readiness of Human Resources (HR) teaching staff, building facilities, infrastructure and students of FEBI UIN North Sumatra Medan itself, in terms of implementing the KKNI-based curriculum program. .

Evaluation and qualitative research approach, because the focus of this research is on observation and naturalistic setting (Rahmat, 1984: 25). Collecting research data using observation techniques, interviews and documentation studies. Furthermore, the data were analyzed using data reduction techniques, data presentation and drawing conclusions. Then, test the validity of the research data using the triangulation technique (Assingkily, 2021).

\section{RESULTS AND DISCUSSION}

\section{Evaluation of KKNI-Based Curriculum Context at FEBI UIN North Sumatra}

\section{Medan}

Implementation of the KKNI-Based Curriculum at UIN North Sumatra Medan refers to the legal basis, namely, Law Number 20 of 2003 concerning the National Education System. It is contained in Article 4 paragraph (2) which states that education is held as a systemic unit with an open and multi-meaning system (Wijaya, 2019: 361). 
Furthermore, the derivative of the law is Presidential Regulation Number 8 of 2012 which is an elaboration of higher regulations. The contents and objectives explain the 5 Chapters, namely: Chapter I on General Provisions, Chapter II on Levels and Equalization, Chapter III on the Implementation of the IQF, Chapter IV on Transitional Provisions, and Chapter V on Closing Provisions.

Article 1 paragraph (1) explains that what is meant by the Indonesian National Qualifications Framework (KKNI) is a framework of competency qualifications that can juxtapose, equalize, and integrate the fields of education and the field of job training and work experience in the context of granting and recognizing work competencies in accordance with structure of work in various fields.

Responding to this regulation, the Chancellor of North Sumatra UIN immediately followed up by issuing a Decree of the Rector of North Sumatra UIN Medan Number 227 of 2015 concerning Academic Quality Standards, which can be seen in article 3.in Faculty of Economics and Islamic Business (FEBI) State Islamic University (UIN) North Sumatra Medan, as part of the obligation to carry out the existing regulations.

In evaluating the context of the KKNI-based curriculum at FEBI UIN SU Medan, Syafaruddin (2011: 90-92) explained that planning is needed as a process of determining activities to be carried out in the future in achieving educational goals, including higher education goals.

At this planning stage, it can be seen from the program run by lecturers at FEBI UIN North Sumatra Medan before conducting lectures there must be an RPS (Semester Learning Plan) for lecturers who teach in Study Programs related to the 6 tasks of the KKNI. Furthermore, this written plan related to the IQF also requires socialization efforts as a step to disseminate information to stakeholders in FEBI. In relation to this activity, Andri Soemitra said:

"Indeed, we, FEBI UIN Sumut Medan, have started step by step from the process of preparing the initial curriculum, this is certainly related more to the condition of our study program, this is generally a new study program. So when in the process of submitting the study program, the curriculum was designed based on the KKNI from the start. And it's in study manuals and academic manuals. So if we look at the academic manual for the FEBI UIN Sumut Medan, we have formulated our curriculum based on the KKNI. Then, regarding the implementation of this curriculum, we usually share this curriculum with lecturers as our spearhead in class. Now the lecturers then formulate the curriculum into their respective courses. Later they make a syllabus, they make a lesson plan that's all, Indeed, the initial guidelines were already curriculum-based with the Indonesian national qualification framework. So far, as far as I know, the FEBI UIN Sumut Medan has thoroughly implemented the 
KKNI for the courses taught by the lecturers." (Interview with the Dean of FEBI UIN SU Medan, 1 November 2019, 13.00 WIB)

Based on the results of the interview above, it can be seen that FEBI UIN North Sumatra fully carries out the learning and teaching process by referring to the KKNI-Based Curriculum Program as required by the government and the Decree of the Rector of UIN North Sumatra Medan Number 227 of 2015 concerning Academic Quality Standards. According toWibowo (2011), the policy of higher education academic quality is the standardization of the determination of shared goals, adjustments to community needs, and achievement of the vision, mission and goals of the institution.

Supporting excerpts from previous interviews, Muhammad Yafiz informed:

"First, the IQF curriculum, this is in FEBI, yes, at FEBI, we have indeed formulated the IQF curriculum from the beginning, to be precise since the release of laws and regulations or the provisions of the IQF were released. Second, after the release of the law, of course we will adjust it to the conditions in the field. This means that everything must be carefully and measurably prepared to comply with the KKNI. Third, after these provisions have been reached, we will immediately adjust them to the conditions of the IQF. This means, since the law and policy of the Chancellor of UIN SU Medan came out, that FEBI has directly implemented the KKNI-based curriculum. Of course, this is an opportunity to improve the quality and quality of students and lecturers in the FEBI UIN SU Medan environment. so that, We, as education providers, make every effort to study and apply them properly and in a planned manner." (Results of interview with Deputy Dean I FEBI UIN SU Medan, 1 November 2019, 15.00 WIB).

Deputy Dean I FEBI UIN Sumut Medan Muhammad Yafiz also on that occasion explained, indeed the implementation of the KKNI-based curriculum at FEBI UIN Sumut Medan still refers to the vision and mission of UIN Sumut Medan. KKNI, which in its rules cannot necessarily be enforced as a whole, but sees the readiness of the campus to implement it. Thus, the purpose of the campus profile will be guaranteed by being able to adopt laws and regulations to ensure KKNI at FEBI UIN SU Medan.

Furthermore, the socialization carried out also had a comprehensive impact on educators and education staff at FEBI UIN North Sumatra Medan, so that through the application of the KKNI it was possible to clarify the profile of "ready to use" graduates and be accepted by various jobs in accordance with their respective qualifications and areas of expertise. According to Duaty (2017) socialization is very important as an effort to grow character and create organizational culture in an educational institution. The following is a picture of the socialization of the KKNI in the FEBI UIN, North Sumatra, Medan. 


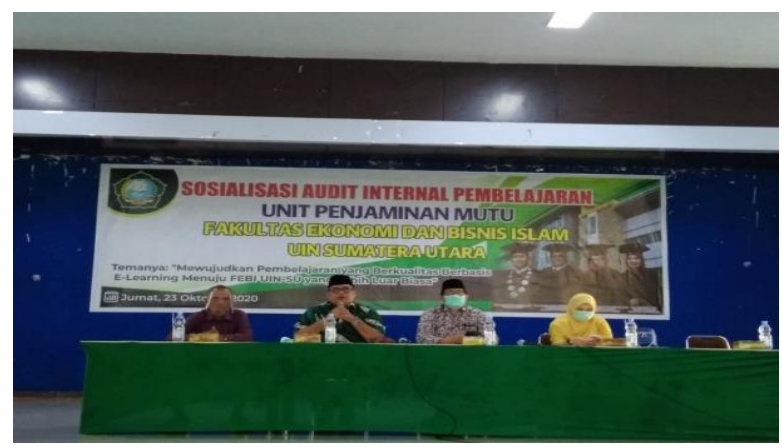

Figure 1. Learning Socialization of the Quality Assurance Unit FEBI UIN North Sumatra

\section{Medan}

Efforts to socialize the KKNI-based curriculum at FEBI UIN North Sumatra Medan were also delivered through lecturer meetings (PNS, BLU, honorary). As stated by Nurul Jannah (one of the FEBI lecturers):

“... yes sir, we were indeed invited to a lecturer meeting regarding the socialization of the KKNI, regarding the curriculum based on the KKNI this is the curriculum used by universities for its use, of course, in order to improve the level of the university. And we know it from the socialization conducted by the campus. Even the follow-up to that is the implementation of rules from the campus for all lecturers to apply the IQFbased curriculum". (Results of interview with Lecturer, 20 October 2019, at 07.00 WIB)

Supporting the interview excerpt above, the following is a picture of the activities of the FEBI lecturer meeting at UIN North Sumatra Medan.

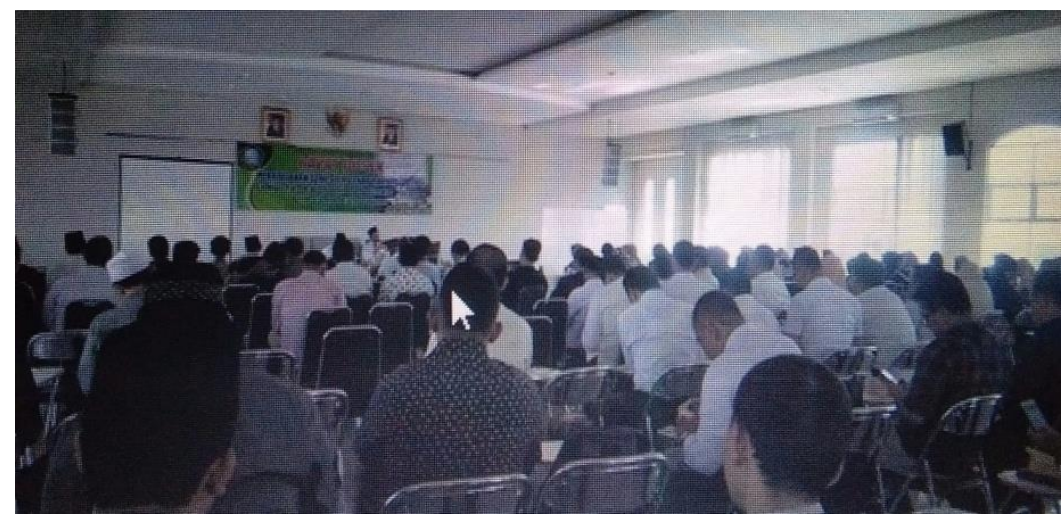

Figure 2. Lecturer Meeting and KKNI Socialization

Regarding the picture above, one of the FEBI lecturers said:

"I'm a lecturer who passed the CPNS in 2019 yesterday, after entering UIN North Sumatra Medan, we have a briefing with friends, namely lecturer nurseries. Well, in the lecturer nursery there is a curriculum training where the preparation of the RPS is in accordance with the KKNI and SNPT. That was the first time I knew about it because I didn't have the basics to be a lecturer, but after becoming a lecturer there was a briefing, where the preparation of the RPS was in accordance with the KKNI and SNPT." (Results of interview with Juliana, 20 October 2019, at 09.00 WIB) 
Based on this interview, it is clear that there has been socialization of the KKNI-based curriculum conducted by the campus for lecturers to provide them with a clear understanding of what the KKNI is and the purpose of implementing the KKNI-based KKNI on the FEBI campus of UIN North Sumatra Medan.

Furthermore, the faculty leadership also actualizes the plans that have been socialized to lecturers and stakeholders in the FEBI UIN SU Medan environment by carrying out several things, including lecture contracts between lecturers and students, making assignment agreements, and completing compulsory courses. The implementation of the KKNI-based curriculum program is very well understood and can be done well, because good socialization is carried out to all components at FEBI UIN North Sumatra Medan. In addition, in stages from the University (UIN) to the Department at FEBI, UIN North Sumatra, Medan, applies the KKNI-based curriculum.

\section{Evaluation of KKNI-Based Curriculum Input at FEBI UIN North Sumatra Medan}

The definition of evaluation is an assessment. In the Oxford dictionary, evaluation is to find out, decide the amount or value (Arikunto, et.al., 2014: 1). While the understanding of the program is divided into two, namely, specific and general understanding. According to a general understanding, the program can be interpreted as a "plan" so the program is a unit or a unit of activity, the program is a system, namely a series of activities that are carried out not only once but continuously. of a policy, takes place in a continuous process, and occurs in an organization that involves a group of people (Arikunto, et.al., 2014: 4).

The meaning of program evaluation itself undergoes a process of stabilization. A well-known definition for program evaluation was put forward by Ralfh Tyler, who said that program evaluation is a process to find out whether educational goals have been realized. The definition that is more accepted by the wider community is put forward by two evaluation experts, namely Cronbach \& Stufflebeam (1963: 5), stated that program evaluation is an effort to provide information to be conveyed to decision makers.

In implementing the program at FEBI UIN North Sumatra, an evaluation will be carried out on the implementation of learning programs based on the KKNI-based curriculum, as based on the Quality Manual of UIN North Sumatra Medan explained about Self Evaluation, namely: First, self-evaluation is carried out by the University, Faculty, Postgraduate, Department /Study Program, Pusbinsa, Libraries, LP2M, and LPM. The second self-evaluation is carried out to find out the obstacles that occur in the educational process. 
Third, LPM makes a self-evaluation format that is given to each unit. Fourth, the results of self-evaluation from each unit are reported to their respective leaders.

For this reason, all components, both lecturers and other education staff, must evaluate in order to see and improve the obstacles that exist in the field. Evaluation of the KKNI-based curriculum program at FEBI UIN Sumut Medan according to Andri Soemitra when interviewed explained:

"The evaluation that we do is usually through the LPM, so later there will be a content evaluation conducted by the LPM. The content will later be checked whether the lectures run by the lecturer in question are in accordance with the syllabus and lesson plans that he has prepared or not. This means that we see the compatibility between the learning plan and the actuality in the field/in the room, well, that's it. The results of this evaluation are usually reported first to the quality assurance agency. So we have a faculty quality assurance agency, there is also a quality assurance agency at the university level. Then, to the lecturer concerned, usually in the lecturer meeting we will also convey EDOM (Lecturer Evaluation by Students) related to the implementation of teaching and learning activities.

Based on the interview above, it can be seen that FEBI UIN North Sumatra conducts an evaluation of the KKNI-based curriculum program and it is carried out by UPM as a quality assurance institution at the faculty level. The content being evaluated is in the form of lectures conducted by lecturers with a syllabus (RPS) which was previously submitted to the academic field before the lecture was carried out. Furthermore, Fachri (2018) explained that the urgency of learning evaluation in education is minimal for knowing whether the implementation of the learning process is going well and in accordance with the learning that has been given by each lecturer to the academic field.

\section{Evaluation of the KKNI-Based Curriculum Process at FEBI UIN North Sumatra}

\section{Medan}

Based on the results of observations and interviews with respondents and review of documents, from some of these questions the researchers found various answers related to the depth and information, knowledge and experience of each respondent, as according to respondent Andri Soemitra as follows:

"The evaluation he does is usually with an LPM evaluation, so later there will be a content evaluation conducted by LPM. The evaluation of the content was carried out by looking at whether the lecture was carried out by the lecturer correctly and the syllabus and learning plans previously prepared by each lecturer. This is done to see if the learning plan matches the reality in the room." (Results of an interview with the Dean of FEBI UIN SU Medan, 1 November 2019, at 13.00 WIB). 
According to the Dean, the results of this evaluation will be reported first to the LPM of the faculty and the LPM of the university. In addition, there are also submitted to the lecturer concerned. Usually, at the lecturer meeting, Edom (lecturer evaluation is carried out by students) is delivered by students related to the implementation of learning and teaching. In this regard, Solihin (2019) added the importance of higher education institutions designing information systems on evaluation of lecturers by students (EDOM). This is done as an effort to measure the performance of lecturers (Harisantoso, 2012).

The following shows a picture of the lecturer's evaluation activities at the beginning of the lecture

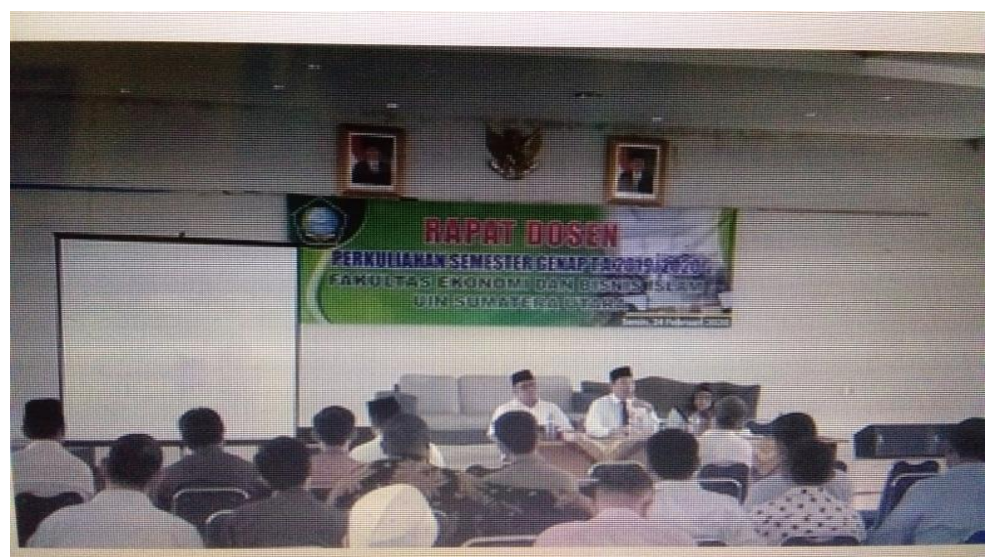

Figure 3. Meetings and Initial Evaluation of Lecturers of FEBI UIN SU Medan

Based on information from the faculty, usually the results of the evaluation will be brought to the leadership meeting to determine further policies from the evaluation results. For example, there are several lecturers in the FEBI UIN Sumut environment in the implementation of their teaching who are considered not to meet the provisions or criteria, then they will be given action. Especially with the KKNI, of course there are tools or instruments that are easiest to see, that is through the RPS. So, at the beginning of the meeting, all lecturers were asked to submit RPS. Later in the RPS, it will clearly explain the achievement of 4 components related to the IQF, namely, attitudes, knowledge, special skills, and general skills.

\section{Product Evaluation of KKNI-Based Curriculum at FEBI UIN North Sumatra Medan}

To get the product (results) of the IQF-based curriculum, here the author will discuss a little about the meaning of learning. This is because the product of the curriculum program in education is an accumulation of the learning process. 
Blearning is defined. First, it results in changes and new abilities. Second, the change or new ability does not last for a moment. Third, changes or new abilities occur because of effort (deliberately), practice and experience. Fourth, the changes or new abilities do not arise because of the growth process or changes in physical conditions (Nasution, 2018: 52).

The learning outcomes cover five abilities, namely, intellectual skills, cognitive strategies, verbal information, motor skills and attitudes. Learning outcomes emphasize more on mastery of actual abilities obtained by a person after studying subjects at one level of educational program within a certain period of time, which is measured by a certain measuring instrument, namely the learning achievement test (study achievement test) (Nasution, 2018: 52).

Moving on from the theory above, the next step is moving towards the results of observations and interviews with respondents and reviewing documents, from these several questions the researchers found various answers related to depth and information, knowledge and experience of each respondent, as according to respondent Andri Soemitra, as following:

"The pattern of implementation model carried out at FEBI UIN North Sumatra with an evaluation of the KKNI-based curriculum is the term conveyed by the Dean, namely the upstream-downstream model. Upstream and downstream he means starting from the initial design of the curriculum, then the curriculum is distributed to courses, then we will see the courses later on, we will see the RPS, see the points and what their achievements are, then the evaluation is carried out 2 times a year. That is what is called Edom." (Results of interview with the Dean of FEBI UIN SU Medan, 1 November 2019, at 13.00 WIB)"

Furthermore, the evaluation of the KKNI process was also observed from the acquisition of student learning scores referring to the GPA (cumulative achievement index). In this regard, Siadari (2020) explained that the IQF-based curriculum has an influence on student learning achievement, and is measured based on the student's cumulative achievement index. The following shows the GPA percentage of FEBI UIN North Sumatra Medan students.

Table 1. Percentage of GPA of FEBI UIN SU Medan Students

\begin{tabular}{|l|l|}
\hline \multicolumn{2}{|c|}{ STUDENT GPA VALUE } \\
\hline \multicolumn{1}{|c|}{ GPA } & \multicolumn{1}{c|}{ PERCENTAGE } \\
\hline $2.7-2.9$ & 0 PERCENT \\
\hline $3.0-3.49$ & 80 PERCENT \\
\hline $3.5-3.79$ & 15 PERCENT \\
\hline $3.8-4.0$ & 5 PERCENT \\
\hline
\end{tabular}


This data shows that there are no student GPA scores that are in the number 2.7-2.9. So it can be seen that students as a whole are able to pass numbers that are below the standard academic value. Even in this data, it can be seen that the percentage of GPA values that dominate is in the number 3.0-3.49. And the number that is quite encouraging is that there are 20 percent of students' GPAs reaching 3.5-40.

In addition, the Head of the Academic Subdivision when asked to explain that starting from 2018 there were 715 graduates/graduates who graduated. Furthermore, in 2019 as many as 573 graduates were graduated. As for the aspect of the teaching staff (lecturers), it is important to evaluate the RPS, the consistency of the RPS with what is being taught, the discipline of the lecturers and attendance in providing the learning process to students.

Based on the evaluation of the KKNI-based curriculum product, an upstreamdownstream model was conducted. Upstream-downstream what he means is starting from the initial design of the curriculum and then the curriculum is distributed to courses, then the courses will be seen by the RPS, the points and achievements are like, then the evaluation is carried out for a year. For example, student success can be seen from the graduates of FEBI UIN North Sumatra in 2018 as many as 715 graduates/graduates and in 2019 as many as 573 graduates. And that is supported by the overall GPA percentage of FEBI UIN North Sumuatera students per year. If you look at the percentage, it is found that 0 percent GPA 2.72.99 , then 80 percent GPA $3.0-3.49$, then 25 percent GPA $3.5-3.79$ and finally there is 5 percent GPA 3.8-3.4. 4.0.

\section{CONCLUSION}

Based on the results of the study, it was concluded that (1) Context, from this aspect, FEBI UIN North Sumatra Medan applies a KKNI-based curriculum referring to Presidential Regulation Number 8 of 2012; (2) Input, including lecturer's RPS, quizzes, assignments, learning participation, mid-semester exams and end-of-semester exams; (3) Process, including monitoring of internal quality assurance units at the FEBI and university levels at UIN North Sumatra Medan, as well as external quality assurance in the context of institutional and study program accreditation; (4) Product, through formative evaluation (such as group assignments, quizzes, individual assignments, exams) and empirical evaluation (behavior and student participation in the learning process).

\section{BIBLIOGRAPHY}


Arikunto, Suharsimi, et.al. (2014). Evaluasi Program Pendidikan (Pedoman Teoritis Praktis Bagi Mahasiswa dan Praktisi Pendidikan). Jakarta: Rineka Cipta.

Assingkily, Muhammad Shaleh. (2021). Penelitian Tindakan Kelas (Meneliti dan Membenahi Pendidikan dari Kelas). Medan: CV. Pusdikra Mitra Jaya.

Casmini. (2014). "Evaluasi dan Peninjauan Kurikulum BKI Berbasisi KKNI” Jurnal Hisbah, 11(1). http://202.0.92.5/dakwah/hisbah/article/view/156.

Cronbach, L.E. (1963). Course Improvement Through Evaluation dalam Educational Evaluation: Theory and Practice, ed.Worthen, B.R., dan Sanders, J.R. California, Belmont: Wadworth Publishing Co.

Daulay, Haidar Putra. (2019). The Dynamic of Islamic Education in South East Asia. Medan: Perdana Publishing.

Dikti. (2010). Buku Pedoman KKNI. Jakarta: Kemendiknas.

Duaty, Sora Devina. (2017). "Sosialisasi Budaya Organisasi pada Mahasiswa di Universitas Pembangunan Nasional "Veteran" Yogyakarta Sebagai Kampus Bela Negara" Skripsi. Yogyakarta: UPN Veteran. http://eprints.upnyk.ac.id/11540/.

Fachri, Moh. (2018). "Urgensi Evaluasi Pembelajaran dalam Pendidikan” Edureligia, 2(1). https://doi.org/10.33650/edureligia.v2i1.758.

Giamellaro, Michael, et.al. (2017). "Curriculum Mapping as a Strategy for Supporting Teachers in the Articulation of Learning Goals" Journal of Science Teacher Education, 28(4). https://doi.org/10.1080/1046560X.2017.1343603.

Harisantoso, John. (2012). "Pengukuran Kinerja Dosen Melalui EKD (Evaluasi Kinerja Dosen) STKIP PGRI Situbondo Berdasarkan Persepsi Mahasiswa" Sainteks, 9(2). http://www.jurnalnasional.ump.ac.id/index.php/SAINTEKS/article/view/272.

Hutabarat, Binsar Antoni. (2017). Evaluasi Kebijakan KKNI Bidang Pendidikan Tinggi. Jakarta: PPs UNJ.

M., Harden Ronald. (2000). The Integration Ladder: a Tool for Curriculum Planning and Evaluation. Blackwell Science Ltd., Medical Education.

Nasution, S. (2008). Berbagai Pendekatan dalam Proses Belajar dan Mengajar. Jakarta: Bumi Aksara.

Rahmat, Jalaluddin. (1984). Metode Penelitian Komunikasi Dilengkapi Contoh Analisis Statistik. Bandung: Remaja Rosdakarya.

Siadari, Grace. (2020). "Pengaruh Kurikulum Berbasis KKNI, dan Manajemen Waktu, Terhadap Prestasi Belajar Mahasiswa Program Studi Pendidikan Ekonomi Stambuk 2016" Skripsi. Medan: UNIMED. http://digilib.unimed.ac.id/41860/.

Siagian, Beslina Afriani \& Golda Novatrasio. (2018). "Analisis Penerapan Kurikulum Berbasis KKNI di Universitas Negeri Medan" Pedagogia: Jurnal Ilmu Pendidikan. http://jsp.uhn.ac.id/wp-content/uploads/2019/01/04-Beslina.pdf.

Siregar, Parluhutan. (2019). Rancang Bangun Pendidikan Berbasis Paradigma, Wahdah Al'ulum di UIN Sumatera Utara. Depok: Rajawali Pers.

Solihin, Hanhan Hanafiah. (2018). “Analisis dan Perancangan Sistem Informasi Evaluasi Dosen oleh Mahasiswa di Lingkungan Universitas Sangga Buana Bandung” JUMANJI: 

Jurnal
Masyarakat
Informatika
Unjani,
2(2).

http://jumanji.unjani.ac.id/index.php/jumanji/article/view/33.

Syafaruddin. (2011). Pengelolaan Pendidikan: Mengembankan Keterampilan dan Manajemen Pendidikan Menuju Sekolah Efektif. Medan: Perdana Publishing.

Syafaruddin. (2012). Inovasi Pendidikan, Suatu Analisis Terhadap Kebijakan Baru Pendidikan. Medan: Perdana Publishing.

Syafaruddin \& Amiruddin MS. (2017). Manajemen Kurikulum. Medan: Perdana Publishing.

Thabrani. (2019). Evaluasi Manajemen Pembelajaran di MAN Rantau Prapat. Medan: PPs UIN Sumut.

Westbury, Ian. (2016). "State-Based Curriculum-Making: The Illinois Learning Standards" Journal of Curriculum Studies, 48(6). https://doi.org/10.1080/00220272.2016.1186740.

Wibowo, Erwin Dwi Edi. (2011). "Kebijakan Mutu Akademik Pendidikan Tinggi” Majalah $\begin{array}{lll}\text { Ilmiah Universitas Pandanaran, } & \text { 9(20). }\end{array}$ http://jurnal.unpand.ac.id/index.php/dinsain/article/view/8.

Wijaya, Candra. (2019). "Prinsip-Prinsip Pelaksanaan Pengembangan Kurikulum Kerangka Kualifikasi Nasional Indonesia (KKNI)" dalam buku (Ed. Mesiono dkk.), 70 Tahun Prof. Haidar Putra Daulay, MA, Medan: Perdana Publishing. 